\title{
An Extend of Farm Diversification in Cauvery Delta Zone - A Spatial and Temporal Analysis
}

\author{
J. Kavipriya ${ }^{1}$, K. Mahandrakumar ${ }^{1 *}$, J.S. Amarnath ${ }^{2}$ and M. Prahadeeswaran ${ }^{2}$ \\ ${ }^{1}$ Department of Agricultural Extension and Rural Sociology, Agricultural College and \\ Research Institute, Madurai 625104 TN, India \\ ${ }^{2}$ Department of Agricultural Economics, Agricultural College and Research Institute, \\ Madurai 625104 TN, India \\ *Corresponding author
}

\section{A B S T R A C T}

\begin{tabular}{|c|c|}
\hline Keywords & This paper explore spatial and temporal dimensions of farm diversification of Cauvery \\
\hline $\begin{array}{l}\text { Farm } \\
\text { diversification, } \\
\text { Spatial and } \\
\text { temporal, } \\
\text { Diversification } \\
\text { index, Cauvery } \\
\text { delta zone }\end{array}$ & $\begin{array}{l}\text { Delta Zone (CDZ) for } 20 \text { years. In addition, it focuses on percentage of deviations from } \\
\text { average area under cultivation of major crops in CDZ. Paddy is the major crop cultivated } \\
\text { in CDZ. It accounted for nearly } 65 \text { percent of the gross cropped area. Recently farmers in } \\
\text { the CDZ are shifting from paddy to diversified crops. Hence to examine this issue the } \\
\text { study was taken up. The major districts comes under CDZ such as Trichy, Tanjore, } \\
\text { Thiruvarur, Nagapatinam, Ariyalur and Cuddalore districts were taken for the study. } \\
\text { Secondary data were collected from Season and Crop Report of Tamil Nadu from } 1996 \text { to }\end{array}$ \\
\hline Article Info & $\begin{array}{l}\text { 2016. Among various Crop diversification index, Herfindhal Index, Simpson Index, } \\
\text { Entropy Index, Modified Entropy Index and Composite Entropy Index were taken for the }\end{array}$ \\
\hline $\begin{array}{l}\text { Accepted: } \\
12 \text { April } 2019 \\
\text { Available Online: } \\
10 \text { May } 2019\end{array}$ & $\begin{array}{l}\text { present study. The area of pulses and cotton increased among all the districts of CDZ, but } \\
\text { the area under water intensive requirement crops like sugarcane and banana area have } \\
\text { decreased. }\end{array}$ \\
\hline
\end{tabular}

\section{Introduction}

Cauvery delta zone lies in the eastern part of Tamil Nadu. Trichy, Tanjore, Thiruvarur, Nagapatinam, Ariyalur and Cuddalore are the major Cauvery delta districts in Tamil Nadu. There are reports that there was a shift to cash crop production to increases the income of the farmers in the farming. The extent of crop diversification in Cauvery delta zone was not yet known. Therefore the study was undertaken to find the spatial and temporal dimensions of farm diversification especially in Cauvery delta zone

\section{Materials and Methods}

To find out the extend of diversification in Cauvery Delta Zone, secondary data collected from Season and Crop Report of Tamil Nadu (1996-97 to 2015-16) was analyzed. Different types of diversification index like Herfindahl Index, Simpson Index, Entropy Index, Modified Entropy Index and Composite 
Entropy Index was used to measure the tendency of diversification over time.

All the following indices are based on the proportion of area under crop in a geographical area. That is

$$
p_{i}=\frac{\text { Area under Crop } i}{\text { Gross Cropped Area }}
$$

\section{Herfindahl Index (HI)}

The Herfindahl Index is the sum of squares of the acreage proportion of each crop in the total cropped area. That is,

$$
H I=\sum_{i=1}^{i=N} p_{i}^{2}
$$

Where $\mathrm{N}$ is number of crops grown in the region during the year.

When ${ }^{H I}$ is mimimum $\quad\left(=\frac{1}{N}\right)$, diversification is maximum.

When $H I$ is maximum $\quad(=1), \quad$ complete specialization occurs as $\mathrm{N}=1$

\section{Simpson Index (SI)}

Another index termed Simpson Index is used to calculate the extend of horizontal diversification in the study area

$$
\mathrm{SI}=1-\sum_{i=1}^{i=N} p_{i}^{2}
$$

The Simpson Index increases with an increase in diversification.

When SI is maximum $\left(=1-\frac{1}{N}\right)$, diversification is maximum.

When SI is minimum $(=0)$, complete specialization occurs.

\section{Entropy Index (EI)}

This is the widely used index by the researchers. Entropy Index increases with increase with an increase in diversification. It is defined as

$$
E I=-\sum_{i=1}^{N} p_{i} \ln \left(p_{i}\right)
$$

It reaches the value of $\ln (\mathrm{N})$ when

$$
p_{i}=\frac{1}{N}(i=1,2,3 \ldots N) \text {. }
$$

When $E I$ is maximum $[=\ln (N)]$, maximum diversification occurs.

When $E I$ is minimum $\quad(=0), \quad$ complete specialization happens as there is only one crop was grown.

\section{Modified Entropy Index (MEI)}

This index is defined as MEI $=-\sum_{i=1}^{N} p_{i} \log { }_{N}\left(p_{i}\right)$ and it is similar to the Entropy Index except in the base of logarithm. Here the base in N.

When ${ }^{M E I}$ is maximum $\quad(=1)$, diversification is maximum.

When ${ }^{M E I}$ is minimum $\quad(=0)$, specialization occurs.

MEI has advantage over the MI that it rank the special diversification. This is possible as MEI provides a uniform and fixed scale which used as a norm for comparison and ranking the regions.

\section{Composite Entropy Index (CEI)}

This index possesses all desirable properties of MEI and it is used to compare the 
diversification across the locations having different number of activities. It gives due weight to the number of activities. It is defined as

$$
\begin{aligned}
& C E I=-\left(\sum_{i=1}^{N} p_{i} \log { }_{N}\left(p_{i}\right)\right)\left(1-\frac{1}{N}\right) \text { or } \\
& C E I=M E I \times\left(1-\frac{1}{N}\right)
\end{aligned}
$$

When $C E I$ is maximum (=1), diversification is maximum.

When $C E I$ is minimum $\quad(=0)$, specialization occurs.

\section{Results and Discussion}

The spatial and temporal dimension of farm diversification of Cauvery Delta Zone were studied using various indices. All the indices other than Herfindhal increased with increase in diversification. A high index value of SI, EI, MEI and CEI shows increased diversification and low specialization. In case of Herfindhal index, the maximum value represents low diversification whereas the minimum value represents higher diversification.

From the table 1, Herfindhal index value for Trichy district lies between 0.37 and 0.74 , Cuddalore district value ranges between 0.16 to 0.21 , Tanjore district ranges between 0.32 to 0.51 , Thiruvarur district ranges between 0.39 to 0.66 , Ariyalur lies between 0.06 to 0.08 and Nagapattinam district lies between 0.39 to 0.59 . This shows clearly that in trichy district the HI index value is comparatively high which revealed that there is less diversification compared to other districts. Even though the Government of Tamil Nadu implemented various schemes like NADP, NFSM, NMOOP, ISFM, IAMWARM, etc. for delta farmers, diversifications is very low.
Simpson index value for Trichy district varies between 0.26 to 0.63 , Tanjore district varies between 0.49 to 0.68 , Thiruvarur district varies between 0.34 to 0.61 , Cuddalore district ranges between 0.79 to 0.84 , Nagapattinam ranges between 0.41 to 0.61 and Ariyalur ranges between 0.92 to 0.94 . Even though, it does not provide any clear cut trend of change, a slight change towards diversification was observed.

The entropy index value for Trichy district is between 1.25 and 1.67, concurrently followed by Tanjore district 0.95 and 1.45 , for Thiruvarur district varies between 0.47 and 1.22, Ariyalur district varies between 1.03 and 1.55, Cuddalore district varies between 1.09 and 1.40 and in Nagapattinam district varies between 1.22 and 1.66. High index value proven that there is a significant level of farm diversification occurs in the area.

Among the Cauvery delta zone the MEI of Trichy district goes upto 0.54 to 0.73 followed by Nagapattinam districts 0.53 to 0.72 . The index value for Tanjore goes upto 0.41 to 0.65 and Thiruvarur goes upto 0.21 to 0.53 districts respectively. The corresponding values for Ariyalur and Cuddalore district were 0.45 to 0.50 and 0.23 to 0.61 shows that farmers in these regions are progressive towards diversification.

The Composite Entropy Index which overcomes all the limitations of EI and MEI reveals that there is an increase in diversification on Cauvery delta zone from 1996-97 to 2015 -16. CEI value for Trichy district in 1996-67 was 0.51 and it is in 201516 was 0.58 , for Cuddalore district it goes from 0.43 to 0.49 , Tanjore district 0.38 to 0.44 . The index value for thiruvarur district increased from about 0.23 in 1996-97 to 0.43 in 2015-16, for Nagapattinam district 0.47 in 1996-97 to 0.53 in 2015-16 and Ariyalur improved from 0.40 to 0.53 . 
All the five indices showed shift towards diversification. There is a wide fluctuation between all the indices in the study area. The reasons attributed for such diversification in $\mathrm{CDZ}$ are as follows:

1. Price fluctuation during harvesting

2. Lack of minimum support price for paddy

3. The farmers getting higher returns in diversified crop as compared to the conventional crop

4. Farmers in CDZ made use of the resources which is available nearby to them

5. Delay in issuing the amount credited by
Government after procuring the product 6. Vagarious rainfall pattern in recent years 7. The farmers in the delta region are not receiving Cauvery water from Mettur dam in a fixed time and also the water released was not sufficient for traditional crop cultivation

As mentioned earlier the diversification indices only show the extent of diversification, but one has to find out the replacement of major crops in the study area. So the percentage of deviations from average area under cultivation of major crops in CDZ were also studied (Table 2).

Table.1 Comparative status of crop diversification indices for Trichy, Tanjore and Thiruvarur districts of CDZ

\begin{tabular}{|c|c|c|c|c|c|c|c|c|c|c|c|c|c|c|c|}
\hline \multirow[t]{2}{*}{ Year } & \multicolumn{5}{|c|}{ Trichy } & \multicolumn{5}{|c|}{ Tanjore } & \multicolumn{5}{|c|}{ Thiruvarur } \\
\hline & & SI & EI & MEI & CEI & II & SI & EI & MEI & CEI & HI & SI & EI & MEI & \\
\hline 1996-97 & & & & & & 45 & 0.55 & & & & .54 & 0.46 & 0.60 & 0.26 & 0.23 \\
\hline & & & & & & & & & & & & & & & \\
\hline 1998-99 & & & & & & & & & & & & & & 33 & \\
\hline 99-2000 & & & & & & & & & & & & & & 42 & \\
\hline & & & & & & & & & & & & & & & \\
\hline 200 & & & & & & & 0.49 & & & & & & & 45 & .40 \\
\hline 200 & & & & & & & & & & & & & & & \\
\hline 200 & & & & & & & & & & & & & & 41 & \\
\hline 200 & & & & 0.64 & & 12 & & & & & & 0.53 & & 47 & 0.42 \\
\hline 200 & & & & & & & & & & & & & & & \\
\hline 2006 & & & 13 & 0.60 & & 45 & 0.55 & & 0.51 & & & 0.53 & .06 & 46 & 0.41 \\
\hline 2007 & & & & & & & & & & & & & & & 0.47 \\
\hline & & & & & & & & & & & & & & & \\
\hline 200 & & & & & & 0.43 & 0.5 & & & & & 0.54 & 05 & 46 & 0.41 \\
\hline & & & & & & & & & & & & & & & \\
\hline 2011-12 & & 0.42 & 1.4 & 064 & & 04 & & & & 0. & & 0.52 & .02 & 0.44 & 0.39 \\
\hline 2012-13 & & & & & & 042 & & & & & & 0.34 & 0.74 & 32 & 0.2 \\
\hline & & & & & & 0.42 & & & & & & & 1.15 & 0.50 & 0.4 \\
\hline 2014-15 & & 0.26 & 1.59 & 0.69 & 0. & 0.46 & 0.54 & 1.17 & 0.51 & & 0.45 & 0.55 & 1.12 & 0.49 & 0.43 \\
\hline 2015-16 & 0.72 & 0.28 & 1.50 & 0.65 & 0.58 & 0.46 & 0.54 & 1.15 & 0.50 & 0.44 & 0.42 & 0.58 & 1.11 & 0.48 & 0.4 \\
\hline
\end{tabular}


Table.2 Comparative status of crop diversification indices for Cuddalore, Nagapattinam and Ariyalur districts of $\mathrm{CDZ}$

\begin{tabular}{|l|l|l|l|l|l|l|l|l|l|l|l|l|l|l|l|l|}
\hline Year & \multicolumn{4}{|c|}{ CUDDALORE } & \multicolumn{4}{l|}{ NAGAPATTINAM } & \multicolumn{4}{c|}{ ARIYALUR } \\
\hline & HI & SI & EI & MEI & CEI & HI & SI & EI & MEI & CEI & HI & SI & EI & MEI & CEI \\
\hline $\mathbf{1 9 9 6 - 9 7}$ & 0.16 & 0.84 & 1.12 & 0.49 & 0.43 & 0.53 & 0.47 & 1.22 & 0.53 & 0.47 & - & - & - & - & - \\
\hline $\mathbf{1 9 9 7 - 9 8}$ & 0.18 & 0.82 & 1.09 & 0.48 & 0.42 & 0.46 & 0.54 & 1.31 & 0.57 & 0.51 & - & - & - & - & - \\
\hline $\mathbf{1 9 9 8 - 9 9}$ & 0.19 & 0.81 & 1.39 & 0.23 & 0.21 & 0.45 & 0.55 & 1.34 & 0.58 & 0.52 & - & - & - & - & - \\
\hline $\mathbf{9 9 - 2 0 0 0}$ & 0.19 & 0.81 & 1.40 & 0.61 & 0.54 & 0.47 & 0.53 & 1.31 & 0.57 & 0.50 & - & - & - & - & - \\
\hline $\mathbf{2 0 0 0 - 0 1}$ & 0.19 & 0.81 & 1.39 & 0.23 & 0.21 & 0.48 & 0.52 & 1.37 & 0.60 & 0.53 & - & - & - & - & - \\
\hline $\mathbf{2 0 0 1 - 0 2}$ & 0.18 & 0.82 & 1.39 & 0.60 & 0.54 & 0.49 & 0.51 & 1.43 & 0.62 & 0.55 & - & - & - & - & - \\
\hline $\mathbf{2 0 0 2 - 0 3}$ & 0.19 & 0.81 & 1.35 & 0.59 & 0.52 & 0.59 & 0.41 & 1.27 & 0.55 & 0.49 & - & - & - & - & - \\
\hline $\mathbf{2 0 0 3 - 0 4}$ & 0.18 & 0.82 & 1.35 & 0.59 & 0.52 & 0.56 & 0.44 & 1.59 & 0.69 & 0.61 & - & - & - & - & - \\
\hline $\mathbf{2 0 0 4 - 0 5}$ & 0.20 & 0.80 & 1.30 & 0.56 & 0.50 & 0.48 & 0.52 & 1.44 & 0.63 & 0.56 & - & - & - & - & - \\
\hline $\mathbf{2 0 0 5 - 0 6}$ & 0.21 & 0.79 & 1.25 & 0.54 & 0.48 & 0.48 & 0.52 & 1.30 & 0.57 & 0.50 & - & - & - & - & - \\
\hline $\mathbf{2 0 0 6 - 0 7}$ & 0.20 & 0.80 & 1.25 & 0.54 & 0.48 & 0.44 & 0.56 & 1.30 & 0.57 & 0.50 & - & - & - & - & - \\
\hline $\mathbf{2 0 0 7 - 0 8}$ & 0.17 & 0.83 & 1.37 & 0.59 & 0.53 & 0.40 & 0.60 & 1.66 & 0.72 & 0.64 & - & - & - & - & - \\
\hline $\mathbf{2 0 0 8 - 0 9}$ & 0.18 & 0.82 & 1.32 & 0.58 & 0.51 & 0.39 & 0.61 & 1.36 & 0.59 & 0.52 & - & - & - & - & - \\
\hline $\mathbf{2 0 0 9 - 1 0}$ & 0.19 & 0.81 & 1.30 & 0.56 & 0.50 & 0.40 & 0.60 & 1.27 & 0.55 & 0.49 & 0.08 & 0.92 & 1.03 & 0.45 & 0.40 \\
\hline $\mathbf{2 0 1 0 - 1 1}$ & 0.19 & 0.81 & 1.30 & 0.56 & 0.50 & 0.40 & 0.60 & 1.28 & 0.56 & 0.49 & 0.07 & 0.93 & 1.03 & 0.45 & 0.40 \\
\hline $\mathbf{2 0 1 1 - 1 2}$ & 0.21 & 0.79 & 1.28 & 0.56 & 0.50 & 0.42 & 0.58 & 1.25 & 0.54 & 0.48 & 0.08 & 0.92 & 1.11 & 0.48 & 0.43 \\
\hline $\mathbf{2 0 1 2 - 1 3}$ & 0.20 & 0.80 & 1.30 & 0.56 & 0.50 & 0.45 & 0.55 & 1.33 & 0.58 & 0.51 & 0.06 & 0.94 & 1.09 & 0.47 & 0.42 \\
\hline $\mathbf{2 0 1 3 - 1 4}$ & 0.19 & 0.81 & 1.38 & 0.60 & 0.53 & 0.40 & 0.60 & 1.45 & 0.63 & 0.56 & 0.07 & 0.93 & 1.15 & 0.50 & 0.44 \\
\hline $\mathbf{2 0 1 4 - 1 5}$ & 0.20 & 0.80 & 1.34 & 0.58 & 0.52 & 0.43 & 0.57 & 1.42 & 0.62 & 0.55 & 0.06 & 0.94 & 1.11 & 0.48 & 0.43 \\
\hline $\mathbf{2 0 1 5 - 1 6}$ & 0.21 & 0.79 & 1.28 & 0.56 & 0.49 & 0.42 & 0.58 & 1.38 & 0.60 & 0.53 & 0.07 & 0.93 & 1.11 & 0.48 & 0.43 \\
\hline
\end{tabular}

Table.3 Percentage of deviations from average area under cultivation of major crops in CDZ during recent years

\begin{tabular}{|l|l|l|l|l|l|l|l|l|l|}
\hline District & Paddy & $\begin{array}{l}\text { Black } \\
\text { gram }\end{array}$ & $\begin{array}{l}\text { Green } \\
\text { gram }\end{array}$ & Sugarcane & Banana & Gingelly & Groundnut & Cotton & Coconut \\
\hline Cuddalore & 14.2 & 30.39 & 65.19 & -17.08 & 7.19 & -1.54 & -94.23 & 52.86 & -30.32 \\
\hline Trichy & -17.04 & 93.88 & 87.92 & -32.21 & -31.2 & 68.57 & -33.67 & 58.63 & 3.66 \\
\hline Ariyalur & 1.89 & 59.17 & 25.3 & 2.06 & 6.49 & -4.31 & -14.95 & 19.4 & -2.43 \\
\hline Tanjore & 3.91 & 41.38 & 2.34 & -25.65 & -11.46 & -0.53 & -37.29 & 68.69 & 26.91 \\
\hline Thiruvarur & 13.42 & 60.53 & 105.07 & -74.36 & 0.46 & -65.58 & 12.97 & 146.39 & -4.1 \\
\hline Nagapattinam & 1.55 & -8.09 & 64.48 & -32.88 & -6.78 & -44.41 & -42.93 & 62.06 & 2.88 \\
\hline
\end{tabular}

From the table 3, it clearly shows that pulses area were increased in all the major delta irrigated districts of $\mathrm{CDZ}$ and water intensive crops like sugarcane and banana area were decreased. The reason for emergence of this crop can be high returns in low cost. In Trichy district, the groundnut area showed -33.67 deviations followed by banana (-31.2) and paddy (-17.04) deviations. Those crops were replaced by pulses and oil seeds. Farmers in the Cauvery Delta depends on Samba, Navarai, Taladi seasons but now farmers 
switched over to single season of paddy. In Cuddalore district, the major deviation was observed in ground nut cultivation (-94.23) followed by coconut (-30.32), sugarcane (17.08) and gingelly (-1.54). Delay in sugarcane payment and cost of cultivation are counted as the foremost factor for the reduction in sugarcane acreage.

Except Trichy district (-17.04) paddy area in all other districts have low deviation. Even though the farmers are facing severe water problems in CDZ they interested to cultivate paddy for at least one season to meet the household consumption. In Nagapattinam district the area under gingelly (-44.41), sugarcane (-32.88) and groundnut (-42.93) had decreased. The farmers cannot go for deep bore well irrigation in this particular district due to water salinity and also the soil became sterile to give better results in cultivating those crops. The area under sugarcane (-25.65), banana (-11.46) and groundnut $(-37.29)$ are found to be very low in Tanjore district. High infestation of pest and diseases in these crops might be the reason for low diversification. A significant number of the farmers in Tanjore district have shown interest towards organic farming in recent days and they prefer to cultivate pest and diseases resistance crop over input oriented crops.

Despite some district variations, the area of coconut has been increasing in Tanjore (26.91), Trichy (3.66) and Nagapattinam districts (2.88). Being a perennial crop coconut require moderate supervision and does not require more labourers, more inputs might be reasons for such shift.

From the analysis of various indices, it was concluded that all the major districts in Cauvery Delta Zone are moving towards high return crops. Being the rice bowl of Tamil Nadu the Cauvery delta farmers currently cultivating paddy for only one season. Requirement of more number of labourers, Price flutuation, adverse weather condition, high incidence of pest and diseases, high input cost and more water requirement are considering as the major causes for diversification. In spite of introduction of various schemes in paddy, availability of direct procurement centre, credit support from cooperative societies and technical support from agricultural departments, crop diversification was not followed in alarming rate in the major delta districts. The government should take necessary steps to facilitate the farmers in timely release of water for irrigation, payment of insurance during crop failure, reasonable Minimum Support Price at the time of harvest and need based supply of machineries to retain the Cauvery Delta Zone, status of traditional rice bowl of Tamil Nadu.

\section{Acknowledgement}

The first author is grateful to University Grants Commission (UGC) for their continuous guidance and financial support provided through "NET-JRF in Science, Humanities \& Social Sciences Scholarship" for the period of this research work.

\section{References}

Shakya Munesh Kumar, Sonu jain and Badal P. S. 2015. Economic analysis of agricultural diversification in Morena district of Madhya Pradesh based on different farming patterns. International Research Journal of Agricultural Economics and Statistics, Vol 6 (1), pp 100- 105.

Kalaiselvi, V., 2012. An Economic Analysis of Crop Diversification in Tamil Nadu. International Journal of Current Research and Review. Vol 4 (8), pp 147-154. 
Gore, N.H., J.V. Lembhe and P.L. kolekar. 2015. Crop diversification in Akola district. International Research Journal of Agricultural Economics and Statistics, Vol 6 (2), pp 371- 375.

Culas richard and Mahen mahendrarajah. 2005. Causes of Diversification in Agriculture over Time: Evidence from Norwegian Farming Sector. 11th Congress of the EAAE (European Association of Agricultural Economists), Denmark.

Singh Ravendra. 2015. An Analysis of Spatio -Temporal Changes in the Pattern of Crop Diversification in Indian Agriculture. International Research
Journal of Social Sciences, Vol. 4(12), pp 15-20.

Pal swades and Shyamal kar. 2012. Implications of the methods of agricultural diversification in reference with Malda district: drawback and rationale. International journal of food, agriculture and veterinary sciences, Vol 2 (2), pp 97105.

Hirschmann, A., 1964. The Paternity of an Index. American Economic Review, pp. 761- 62.

Department of Economics and Statistics. Season and Crop Report 1996-2016, Tamil Nadu.

\section{How to cite this article:}

Kavipriya, J., K. Mahandrakumar, J.S. Amarnath and Prahadeeswaran, M. 2019. An Extend of Farm Diversification in Cauvery Delta Zone - A Spatial and Temporal Analysis Int.J.Curr.Microbiol.App.Sci. 8(05): 1257-1263. doi: https://doi.org/10.20546/ijcmas.2019.805.143 